\title{
Çocuk edebiyatının geldiği son nokta: Okul öncesi dönem resimli e-kitaplara gelişimsel bir bakış*
}

\author{
The current situation of children's literature: A Developmental overview \\ of the preschool picture e-books
}

\author{
Şuheda Bozkurt Yükçü ${ }^{1}$, Aslı İzoğlu Tok ${ }^{2}$, Saniye Bencik Kangal ${ }^{3}$
}

\begin{abstract}
Makale Geçmişi
Geliş : $\quad 23$ Kasım 2018

Düzeltme : 11 Subat 2019

Kabul : 14 Mart 2019

Çevrimiçi : 20 Mart 2019
\end{abstract}

Makale Türü

Derleme Makale

\section{Article History}

Received : 23 November 2018

Revised : 11 February 2019

Accepted : 14 March 2019

Online : 20 March 2019

\section{Article Type}

Revien Article
Öz: Okul öncesi dönem yașamın ileriki dönemlerine etki eden hassas bir süreçtir. Bu süreçte çocuğun birincil çevresi olan ebeveyn etkileşimlerinin yanında çocuğa sunulacak materyaller, oyuncaklar ve kitaplar gibi uyaran bakımında zengin bir çevre çocuğun gelişimine olumlu yönde katkı sağlayacaktır. Özellikle okul öncesi dönemde çocuk edebiyatı ürünleri, çocuk için uyaran bakımından zengin çevrenin temel unsurları arasında yer almaktadır. Çocuklar için hazırlanan kitaplar, çocuğun okurken zevk almasına, eğlenirken öğrenmesine, hayal dünyasının gelişmesine, dil becerilerine katkı sağlamalı ve kitabın hayatındaki yerini kavramasına yardımcı olmalıdır. Son dönemlerde teknolojik gelişmeler, çocuk edebiyatında da etkisini göstermiş ve resimli e-kitaplar ortaya çıkmıştır. Ancak resimli e-kitapların, çocuğun gelişimi üzerinde nasıl bir etkiye sahip olacağı konusu halen açılı̆ğa kavuşmuş bir konu değildir. $\mathrm{Bu}$ nedenle, resimli e-kitaplara ilişsin gelişimsel bir bakış açısına ihtiyaç duyulmuştur. Bu kapsamda, bu derleme çalışmasında resimli e-kitaplar çocuk edebiyatının geldiği son nokta olarak ele alınmış ve gelişimsel bir bakış açısı ile söz konusu olumlu ve olumsuz özellikleri tartışılmıştır.

Anahtar Kelimeler: Çocuk edebiyatı, E-kitaplar, Okul öncesi dönem

Abstract: The preschool period is a critical process affecting the later stages of life. In this process, a stimulus-rich environment, such as materials to be presented to the child, toys and books, as well as parental interactions, will contribute positively to the development of the child. In this process, it will contribute positively to the development of a stimulus-rich environment such as materials, toys, and books that will be presented to the child. Especially children's literature in preschool are among the basic elements of the environment. Recent technological have also been influential in children's literature and picture e-books have emerged. However, the issue of how picture e-books impact on the child's development is not clear yet. Thus, a developmental view of the picture e-books was needed. In this review study, picture e-books are considered as the current situation of children literature and advantages and disadvantages of picture e-books are discussed with developmental overview.

Keywords: Children's literature, e-books, preschool period

\footnotetext{
* Bu çalışma Uluslararası IV. Çocuk Gelişimi Kongresi’nde sözlü bildiri olarak sunulmuştur.

${ }^{1}$ Hacettepe Üniversitesi, Sağllk Bilimleri Fakültesi, Çocuk Gelişimi Bölümü, suhedabzkrt06@gmail.com, ORCID: https://orcid.org/0000-0001$\underline{6611-4113}$

${ }^{2}$ Hacettepe Üniversitesi, Sağlık Bilimleri Fakültesi, Çocuk Gelişimi Bölümü, izogluasli@gmail.com, ORCID: https://orcid.org/0000-0002-0063$\underline{8448}$

${ }^{3}$ Hacettepe Üniversitesi, Sağılk Bilimleri Fakültesi, Çocuk Gelişimi Bölümü, saniyebencik@yahoo.com, ORCID: https://orcid.org/0000-00022585-5078
}

Atıf için/To cite this article:

Bozkurt Yükçü, Ş., İzoğlu Tok, A., \& Bencik Kangal, S. (2019). Çocuk edebiyatının geldiği son nokta: Okul öncesi dönem resimli ekitaplara gelişimsel bir bakış. Erken Cocukluk Çalş̧malar Dergisi, 3(1), 139-164. doi:http://dx.doi.org/10.24130/eccd-jecs.1967201931122 


\section{SUMMARY}

\section{Introduction}

Preschool period is a critical process in which development progresses in all areas in the fastest way and this development process affects the future periods of life. In this process, the environmental factors as well as child's innate characteristics are also quite important. For this reason, a rich environment in terms of stimulus, such as toys and books, as well as parent interactions, will contribute positively to the development of the child. Children's literature products in the preschool period are among the basic elements of the stimulus-rich environment for children. In this context, it is possible to say that the number of children's picture books has increased. In this study, it is aimed to present a developmental perspective on picture ebooks, which is one of the last points of children's literature.

\section{History of Children's Literature}

When the processes related to the history of children's literature are examined, it is possible to say that Western societies lead the development of children's literature (Ersan, 2014; Kul, 2014; Somer, 2015; Tuncer, 2018). Until the 16th century, while children around the world were seen as small adults, children's rights gained importance, and the opinion that children were separate individuals began to dominate (Kul, 2014; Onur, 2012). However, it is seen that simple and uncomplicated picture books have begun to be made for children apart from increasing value given to the child in the middle of the 19th century. As of the 20th century, it can be said that many picture children's literature products emerged in the dimension that we understand today (Ersan, 2014; Kul, 2014; Sar1, 2006).

\section{Child and E-Book}

There have been many changes in daily life due to the fact that the technological devices have become portable. Many daily activities such as listening to music, watching movies, taking photos can be met with a single technological tool. Likewise, the habit of reading books has become affordable by using these technological tools. E-books developed to meet the needs of daily life are among the concepts that modern technology gives us (Iş1k, 2013). Accordingly, children should have the opportunity to meet e-books (Ersan, 2016).

\section{E-Book History}

In 1971, Michael Hart published the first electronic book in digital format to create an electronic library under the Gutenberg project (Hart, 1992). Thus, it has opened a new page by allowing readers from all over the world to access the books in electronic form and for free. 
When examining the situation in Turkey; at the end of the 1990s, e-books started to attract attention (Soydan, 2012; Öngöz, 2011; Önder, 2011). The e-book is seen widespread especially in the education sector in Turkey. The most important ones were carried out by Ministry of National Education and Anadolu University Open Education Faculty within the scope of the Project of Enhancing Opportunities and Improving Technology (FATIH) (Bozkurt and Bozkaya, 2013; Mutlu, Korkut and Yllmaz, 2006).

\section{E-Book Definition}

The first e-book examples were the printed PDF formats of printed sources. However, technological developments and changes in the supply-demand balance led e-books to become more sources of interaction, visual and auditory experiences. All of these developments led to the emergence of different views on what the e-book concept is.

However, it is thought that defining e-books by classifying e-textbooks, young e-books, adult e-books, picture e-books and taking into account the technological developments will facilitate the consensus in the literature about the definition of this concept. Preschool picture e-books, which are one of the last points of children's literature, can be defined as rich text sources that support the development areas of the child for children aged 3 to 6 years, allow the child to interact with multimedia elements such as audio and visual effects, created or transferred electronically, provide a fun book-reading activity to the child with adult or alone and can be viewed through an electronic device.

\section{E-Book Features}

One of the most important features of the picture e-books is that the parents have the opportunity to see the rewards, alternative applications and comments. Thus, the selection process of books can become healthier and more reliable for families. The implementation of the e-book application at a reasonable price can be used to create a low budget library for families.

\section{Advantages and Disadvantages of E-Books}

Picture e-books are becoming increasingly popular in terms of ease of use, low cost and accessibility (Alpkıray and Samur, 2017; Önder, 2011). Most applications are usually for free (Gönen and Balat, 2002). This situation provides a great convenience for families whose economic level is not conducive to receiving printed books. The biggest disadvantages of picture e-books is electronic access (Soydan 2012). However, it is another disadvantage that the applications are not fully contained in the characteristics of printed books (Sayer, 2013). Another concern is that children are reading these books on screen.

When the literature is examined, it is seen that the studies about e-books are generally related to textbooks or materials in education system. These studies reveal the advantages (Barnyak and McNelly, 2016; İleri Aydemir, Öztürk and Horzum, 2013; Brusilovsky, Chavan and Farza, 2004; McFall, 2005; Schwartzman and 
Tuttle, 2002) and disadvantages (Kropman, Schoch and Teoh, 2010; Lam, Lam, Lam and McNaught, 2009; Woody, Danie and Baker, 2010) of e-books.

\section{A Developmental Overview of Picture E-Books}

Electronic publishing, which is more on the agenda with the use of the Internet, has become more possible for children to access the e-books which is consist of multimedia features and editable font size (Sayer, 2013). These features make the book more interesting for children. As a natural consequence of this, it is thought that the time spent by children with the book may be extended. In addition, picture e-books have become a starting point in terms of ability to read books for preschool children without an adult. Picture ebooks can be customized for individuals with special needs (Öngöz, 2011). However, e-books lead to controversy about children's eye fatigue and screen addiction (Walton, 2007).

\section{Result}

Qualified and unqualified picture e-books can be found together. Like printed books. In fact, the main issue that needs to be discussed is what the quality of the picture e-books is, what should be considered in selecting books and how long the children will spend with picture e-books. In the scope of this study, picture e-books are considered as a variety and richness and as an alternative option rather than replacing the printed books by researchers. 


\section{GİRİŞ}

Okul öncesi dönem, gelişimin tüm alanlarda en hızlı şekilde ilerlediği, kişiliğin temellerinin atıldığı, temel bilgi, beceri ve alışkanlıkların kazanıldığı ve bu gelişim sürecinin yaşamın ileriki dönemlerine etki ettiği hassas bir süreçtir. Bu süreçte, çocuğun doğuştan getirdiği birçok özelliğin yanında çevrenin etkisi de oldukça büyüktür. Bu nedenle çocuğun birincil çevresi olan ebeveynleriyle olan etkileşimlerinin yanında çocuğa sunulacak materyaller, oyuncaklar ve kitaplar gibi uyaran bakımında zengin bir çevre çocuğun gelişimine olumlu yönde katkı sağlayacaktır.

Okul öncesi dönemde çocuk edebiyatı ürünleri, çocuk için uyaran bakımından zengin çevrenin temel unsurları arasında yer almaktadır. Sever (2012) çocuk edebiyatı ürünlerini erken çocukluk döneminden ergenlik dönemine kadar olan süreçte çocukların dil ve anlama düzeylerine uygun, duygu ve düşünce dünyalarını sanatsal bir şekilde yazılı görsellerle zenginleştiren ürünler olarak ifade etmektedir. Edebiyat çocuklara, insanların yaşam deneyimlerine yönelik bilgiler vermekte; güzel olan deneyimlerin yanında, kötü ve üzücü durumlara ait örneklerle hayatın iyi ve kötü yönlerini ele alarak bir gerçeklik algısı oluşturmaktadır. Bu farklı durumlar, çocukların zorluklarla baş etme, sorunlara farklı çözümler geliştirme, diğer insanlara karşı farkındalık geliştirerek empati kurma, yardım etme ve işbirliğinde bulunma gibi olumlu sosyal davranışlarının gelişimine katkı sağlamaktadır (Körükçü, Kapıkıran ve Aral, 2016; Toran ve Dilek, 2017; Woolley ve Cox, 2007).

Çocuklar, yaşamın doğal akışı içerisinde erken yaşlardan itibaren çocuk edebiyatı ürünlerinden resimli çocuk kitapları ile tanışmaktadırlar. Çocuklar; ufuklarını genişletmek, anlayışlarını derinleştirmek ve sosyal kavrayışlarını geliştirmek için kitaba ihtiyaç duyarlar (Veziroğlu ve Gönen, 2012). Resimli çocuk kitapları çocuğun kültürel kimlik geliştirmesine, farklı kültürleri tanımasına katkı sağlamakla birlikte hem resim hem yazı içeriğine sahip olması nedeniyle çocuğun estetik gelişimini desteklerken onu okuma yazmaya da hazırlamaktadır (Yol, 2015). Bunların yanı sıra çocukların dil bilinci ve sevgisi kazanmasında, kelime dağarcığını zenginleştirmede resimli çocuk kitaplarının büyük payı bulunmaktadır (MEB, 2013). Görüldüğü gibi çocuk edebiyatı ürünlerinden biri olan resimli çocuk kitapları çocuğun gelişiminde önemli kazanımlara aracılık eden işlevsel ürünlerdir. Ancak bu kazanımlardan söz edebilmek için resimli çocuk kitaplarının niteliğinden de söz etmek gerekmektedir. Resimli çocuk kitaplarının çocuğun gelişimine katkıları, kitapların nitelikli olması ile de ilişkilidir.

Nitelikli resimli çocuk kitaplarının fiziksel, içerik ve resimleme özellikleri bakımından çocuğun gelişim düzeyine uygun (Toran ve Dilek, 2017), ilgi çekici ve merak uyandırıcı olmaları en önemli özelliklerinden bazıları olarak söylenebilir (Yıldız, Yazıcı ve Durmuşoğlu, 2016). Bunun mümkün 
olması için kitabın yazarının ve çizerinin çocuğun ruhundan anlaması ve dünyaya çocuğun gözünden bakabilmesi gerekmektedir. Kitaplar biçimsel ve içerik özellikleriyle, okul öncesi dönemdeki çocukların öncelikle eğlenme-oynama ve keşfederek öğrenme gereksinimini karşılamalı, onların algısal gelişimine katkı sağlamalıdır (Dağlıŏlu ve Çamlıbel-Çakmak, 2009; Toran ve Dilek, 2017).

Çocuklara başkaları tarafindan okunan, yeni bilgiler veren, var olan bilgilerini pekiştiren ve göze hitap eden kitaplar olan resimli çocuk kitaplarında esas unsur resimdir, metinler ise resmin tamamlayıcısı olarak algılanır (Gönen, Uludağ, Fındık-Tanrıbuyurdu ve Tüfekçi, 2014). Resimlemeler, metinde işlenen konu, olay ve ana fikri kavramaya yardımcı olan bir diğer tamamlayıcı öğe olmanın yanında eseri çekici kılmakta, kitapları sıradanlıktan çıkararak, onların ilgi çekici bir öğrenme aracı olmasını sağlamaktadır (Yıldız, Yazıcı ve Durmuşoğlu, 2016). Resimlemeler, henüz metni okuma becerisine sahip olmayan okul öncesi dönem çocuğu için oldukça önemlidir. Resimlerle kelimelerin uyum ve denge içinde olduğu edebiyat ürünleri; çocuğun duyularını geliştirerek, nesneleri sınıflandırma, gruplandırma, hatırlama ve dikkat etme gibi bilişsel süreçlerin gelişimini destekleyerek, çocuğun zihninde görsel imgelerle kavramların yerleşmesini, kitaplardaki resimleri yorumlarken ve zihinde görüntüsünü oluştururken hayal gücünü aktif kullanmasını sağlayarak düşünme, sorun çözme ve yaratıcıllk becerilerinin gelişimine katkı sağlamaktadır (Veziroğlu ve Gönen, 2012).

Resimli çocuk kitaplarının Türkiye ve Dünya'da günümüze kadar geçirmiş olduğu bir dizi süreç bulunmakta ve bu süreç hala devam etmektedir. Bu nedenle resimli çocuk kitaplarının geldiği son noktalardan biri olan resimli elektronik kitaplara yönelik gelişimsel bir bakış açısı sunmayı amaçlayan bu çalışmada, resimli çocuk kitaplarının dolayısıyla çocuk edebiyatının kısa bir tarihçesine değinilme ihtiyacı duyulmuştur.

\section{Çocuk Edebiyatının Tarihçesi}

Çocuk edebiyatının tarihçesine ilişkin süreçler incelendiğinde Batı toplumlanının çocuk edebiyatının gelişimine öncülük ettiğini söylemek mümkündür. Ancak çocuk edebiyatının tarihsel sürecine bakıldığında doğrudan "çocukluk” kavramının tarihsel süreci ile karşılaşılmaktadır. İlk çağlarda insanlar, nesilden nesile bilgi aktarma yolu olarak sözlü edebiyat ürünlerinden masal, ninni ve hikayeleri kullanmışlardır (Ersan, 2014; Kul, 2014; Somer, 2015; Tuncer, 2018). Bunların kalıcıllğını desteklemek için ise mağara duvarlarına yapmış oldukları resimlemeleri kullanmışlardır. Ancak bu sözlü ürünler ve resimlemeler çocuklar için değil yetişkinler için yapılmışıı. Çocuklar ile ilgili ilk basılı kaynak MS. 105’te II. Yüzyılda geliştirilen sayfa sistemleri ile ortaya çıkmıştır. Bu kitaplar ağaç 
oyma kalıplarının kağıt üzerine basılması ile elde edilmiştir. Daha sonraları Mısırlılar tarafında keşfedilen Papirus ruloları ortaya çıkmaktadır (Kul, 2014).

15. yüzyıla gelindiğinde Rönesans hareketi ve matbaanın gelişimi, edebiyat eserleri için bir dönüm noktası olmuştur. 16. yüzyıl öncesine kadar dünya çapında çocuğa bakış açısı çocukların "küçük yetisskinler” olduğu yönünde olmuştur. 16. Yüzyll ile birlikte değişen dünyada çocuk haklarının önem kazanması ile birlikte çocuklarında ayrı bireyler olduğu görüşü hakim olmaya başlamıştır (Onur, 2012). Önceleri yetişkin kıyafetlerinin sadece boyut olarak küçültülmüş olanlarını giyen çocuklar için onlara özgü kıyafetler, oyunlar, öyküler, şarkılar, müzikler ve daha birçok eğlence unsuru oluşmaya başlamıştır. Yine benzer şekilde kitaplar da ilk kez özellikle çocuklar için uyarlanmaya başlamıştır (Ersan, 2014; Kul, 2014; Sarı, 2006). 17. yüzyıla gelindiğinde ise 1658 yılında Alman eğitimci Johann Amos Comenius, tarafından ilk resimli çocuk kitabı olarak bilinen, siyah beyaz olarak resimlenmiş ve yazıların resimlerden daha fazla yer kapladığı "Orbis Pictus (Resimlerle Görünen Dünya)” isimli kitap yayınlandığı (Börekçi, 2016; Ersan, 2014; Sarı, 2006). Bu kitap resimlemelerin ağaç kalıplarla oyulup bakır klişe tekniği ile basılmış ve çocuklara okuma yazma öğretmek amacıyla kullanılmıştır. Bir diğer önemli gelişme ise -daha yaygın olarak ilk resimli çocuk kitabı olarak bilinen- 1762 yılında Jean-Jacques Rousseau'nun yayınlamış olduğu "Emile" isimli resimli çocuk kitabıdır. Bu kitap bir çeşit çocuk terbiyesi kitabı olarak da görülmekle birlikte annebabalara çocuklarını eğitirken karşılaştıkları sorunların çözümünü sunan bir kitaptır (Ersan, 2014; Sar1, 2006; Tuncer, 2018).

19.yüzyıla kadar olan dönem değerlendirildiğinde çocuk edebiyatı eserlerinin gelişiminin bu süreçte oldukça yavaş olarak nitelendirmek mümkündür (Gönen, 2011). Ancak 19. yüzyıl ortalarında çocuğa verilen değerin giderek daha da çok artması ile birlikte çocuğa özgü tasarımların yapılmaya başlandığı, basit, karmaşık olmayan çocukça kitapların ortaya çıktığ1 görülmektedir (Ersan, 2014; Kul, 2014; Sar1, 2006). 20. yüzyıl itibarıla ise bask1 ve ciltleme anlamında artık günümüzde anladığımız boyutta birçok çocuk edebiyatı ürünün ortaya çıktığı söylenebilir. Çocukların sanat, eğitim ve tarih ile ilgilenmeleri için dergiler, çocuk tiyatroları, çocuk kitapları, ders kitapları ve çizgi romanlara kadar birçok ürün bulunmaktadır (Kul, 2014). 21. yüzyıl, yayıncılı̆̆ın ve dolayısıyla çocuk edebiyatı yayıncıllı̆̆ının bir sektör olarak daha çok belirginleştiği bir dönemdir (Ersan, 2014; Sayer, 2013). Teknolojik gelişmelerin bir sonucu olarak ise elektronik yayıncılık bu dönemde ortaya çıkmış ve çocuk edebiyatı alanına resimli e-kitaplar olarak yansımıştır.

Dünyada bu gelişmeler söz konusu iken ülkemizde çocuk edebiyatının gelişimine baktığımızda dünyadaki gelişmelerden etkilenilmiş olmakla daha yavaş ilerlediğini söylemek mümkündür. 
Ülkemizde de çocuk edebiyatı ile ilgili büyük değişimler dünyadaki tarihsel süreçle benzer şekilde 19.yüzyıl itibarıyla yaşanmıştır. Yazılı çocuk edebiyatı gelişmeden önce tüm dünya çocukları gibi Türk çocukları da masallar, efsaneler tekerlemeler, Nasrettin Hoca fikraları gibi sözlü edebiyat ürünleri ile tanışmışlardır (Gökmen, 2017; Tuncer, 2018). Ancak çocuklar için kitap hazırlama fikri Tanzimat dönemi ile yani 19. yüzyıl ile ortaya çıkmış (Çakmak-Güleç ve Kanat-Soysal, 2018) ve aynı zamanda bu dönemde dünya çocuk klasikleri Türkçe’ye çevrilmeye başlamıştır (Gönen, 2011). Gelişmelerin en önemli noktaya ulaşması ise Meşrutiyetin ilanı ile gerçekleşmiştir. Öğretmen okullarının açılmasıyla, daha çok çocukların şivelerini düzeltmek ve eğitmede işe yarayabilecek manzumeler hazırlamak amacıyla çocuk kitapları hazırlanmışır (Çakmak-Güleç ve Kanat-Soysal, 2018, Kul, 2014; Şirin, 2000).

1970’lere gelindiğinde çocuk yayıncıllı̆̆ tür ve baskı sayısı bakımından önemli gelişmeler göstermiş (Gönen, 2011) ve nitelikli kitaba giden yollar tartışılmaya başlanmıştır. 1974 yılında ressam ve yazar Can Göknil okul öncesi çocuklarına hitap eden ilk resimli çocuk kitabımız olarak nitelendirilebilecek “Kirpi Masalı” isimli eserini yayımlamıştır. Güleç-Çakmak ve Gönen-Sofuoğlu (1997) tarafindan 1974-1993 yılları arasında Türkiye'deki resimli kitaplarının incelendiği çalışmada resimli çocuk kitaplarının yıllarla doğru orantılı olarak sayıca arttığı ancak fiziksel özelliklerinin ise istenilen düzeyde artmadığ1 ve genellikle gerçekçi resimlemelerin kullanıldığı görülmüştür. Gönen, Karakuş, Uysal, Kehci, Ulutaş ve Kahve (2016) tarafindan 2000-2010 yılları arasında Türkiye'de basılan resimli çocuk kitaplarının içerik ve resimleme özellikleri açısından incelendiği bir diğer araştırmada kitapların çoğunlukla renkli olduğu, resmin çerçeve ile metinden ayrılmayıp daha yalın hatlara sahip olduğu, metin dilinin daha yalın ve estetik değerleri geliştiren özelliklere sahip olduğu ortaya konmuştur.

Sonuç olarak çocuk edebiyatınının tarihsel süreç içerisinde biçimsel olarak geçirdiği değişim; biçimsel özellikleri açısından önceleri siyah beyaz olan resimlerin renklendiği, metnin sayfanın büyük bir bölümünü kapladığı kitaplardan resimlerin metinden daha büyük yer kapladığı kitaplara ulaşıldığı, önceleri resmin çerçeve ile metinden ayrıldığı kitapların yerini yalın hatlı resimlerin aldığ1, bask1, ciltleme ve resimleme özelliklerinin gelişme gösterdiği şeklinde özetlenebilir (Börekçi, 2016; Ersan, 2014; Gönen, Karakuş, Uysal, Kehci, Ulutaş ve Kahve, 2016; Kul, 2014; Sar1, 2006). Görüldüğü gibi çocuk edebiyatının dolayısıyla resimli çocuk kitaplarının gelişimi Dünya ve Türkiye'de tarihsel süreç içerisinde oldukça dinamik bir yapıya sahip olmuştur. Çocuklara nitelikli resimli çocuk kitaplarının nasıl ortaya konacağına ilişkin çalışmalar ise hala devam etmektedir. Bu çalışmalar devam ederken resimli çocuk kitaplarının resimleme, baskı ve ciltleme gibi birçok özelliği gelişen teknolojik imkanlar doğrultusunda güncellenmiş ve daha gelişmiş hale getirilmiştir. 
Teknolojik gelişmelerin çocuk edebiyatı açısından son dönemdeki ürünlerinden biri olan, kullanımı henüz ülkemizde yaygınlaşmamış elektronik resimli çocuk kitapları (resimli e-kitaplar) çocuk edebiyatı alanında son zamanlarda dikkat çeken konulardan biri olmuştur.

\section{Çocuk ve E-Kitap}

Teknolojik gelişmeler yaşamın her alanında önemli değişiklikler yaratmıştır. Bu değişiklikler gündelik hayat içerisinde bile belirgin olarak karşımıza çıkmakla birlikte yeni kavramların ve geliştirilmiş teknolojik aletlerin kullanılmaya başlanması ile günlük hayatımıza derinden etki etmeye başlamıştır. Bu kapsamda birçok araştırmacı da çalışmalarında teknolojinin hayatımızın her alanına dâhil olduğunu ifade etmektedir (Aktaş Arnas, 2005; Bozkurt ve Bozkaya, 2013; Ersan, 2016; Işık, 2013; Mutlu, Korkut ve Y1lmaz, 2006).

Teknolojinin ilerlemesi ile birlikte teknolojik aletlerin taşınabilir hale gelmesine bağlı olarak gündelik yaşamda bazı değişiklerin meydana geldiğini söylemek mümkündür. Müzik dinleme, film seyretme, fotoğraf çekme gibi birçok gündelik hayata dair aktivitelerimiz tek bir teknolojik araç ile karşılanabilmektedir. Aynı şekilde kitap okuma alışkanlığı da bu teknolojik araçları kullanarak karşılanabilir hale gelmiştir. Gündelik yaşamdaki ihtiyaçları karşılamaya yönelik geliştirilen elektronik kitaplar (e-kitaplar) da günümüz teknolojisinin bize kazandırdığı kavramlar arasındadır (Iş1k, 2013).

Bilgisayarlardan taşınabilir elektronik cihazlara kadar dijital teknolojinin giderek artan kullanımı sonucunda e-kitaplar da yaygınlaşmış; buna bağlı olarak çocuklar da e-kitaplar ile tanışma imkânı bulmuştur (Ersan, 2016). Bu dönem dünya çapında 20. yüzyılın sonu ile 21. yüzyılın başına denk gelmektedir (Sénéchal ve LeFevre, 2002). Ancak bu süreçte Türkiye'de arz talep dengesinin gözetilerek yayın yapılmasına bağlı olarak yayıncıların elektronik yayıncılık konusunda çekimser kaldıkları görülmektedir (Sayer, 2013). E-kitap konusunda Türkiye'de yapılan lisansüstü tezlerin içerik analizine yönelik bir araştırmada son yıllarda e-kitap yayıncıllk sektörünün de bir ivme kazandığı, belirli yayınevlerinin basılı kitapla eşzamanlı olarak e-kitapları da yayınladıkları, kitap satış sitelerinde aynı zamanda e-kitap satıldığı belirtilmektedir (Alpkıray ve Samur, 2017). Son yıllarda çocukların çeşitli teknoloji araçlarını yoğun bir biçimde kullanması ve çocukların teknolojiyi keşfetmek için çokça firsata sahip olmasına bağlı olarak da e-kitapların kullanımının arttığı söylenebilir (Ihmeideh, 2014).

E-kitapların kullanımındaki artışın bir diğer nedeni olarak basılı kitaplarda içeriği zenginleştirmek için sadece resim veya ses gibi basit öğelerden yararlanılabilirken, e-kitaplara zengin içeriğe sahip 
birçok öğenin eklenebiliyor olması söylenebilir (Daş, Yıldırım, Bölen ve Çeliker, 2013). Bu sebeple ses ve görüntü gibi etkileşimli materyaller ile desteklenen zengin içerikli e-kitaplara ihtiyaç duyulması aslında e-kitapların gündelik hayata daha çok dâhil olmasını sağlamıştır (Daş, Yıldırım, Bölen ve Çeliker, 2013; Ersan, 2016). Bu içerikte zenginleşme ile birlikte hikâye anlatımı farklı boyutlar kazanmıştır. Bu uygulamalarda ses, hareketli resimler, şekiller, etkileşimler ve oyun özellikleri içeren uygulamalara dönüşerek çocukların basılı kitaptan farklı bir okuma biçimi deneyimlemesine olanak sağlamıştır (Aktaş Arnas, 2005; Bozkurt ve Bozkaya, 2013; Ersan, 2016; Işık, 2013; Mutlu, Korkut ve Yılmaz, 2006). E-kitapların ortaya çıkışına olanak sağlayan bu doğal akışın neticesinde e-kitapların tanımlanması ve özelliklerinin belirlenmesi ihtiyacı ortaya çıkmıştır.

\section{E-Kitabın Tanımı}

İlk e-kitap örnekleri basılı kaynakların elektronik ortama aktarılmış pdf formatları olmuştur (Bozkurt ve Bozkaya, 2013; Mutlu, Korkut ve Yılmaz, 2006). Ancak teknolojik gelişmeler ve arz talep dengesindeki değişmeler e-kitapların da daha çok etkileşim, görsel ve işitsel deneyimler sunan kaynaklar haline gelmesine sağlamıştır. Tüm bu gelişmeler e-kitap kavramının ne olduğuna ilişkin farklı görüşlerin ortaya çıkmasına neden olmuştur. Dolayısıyla 1960’lı yılların sonlarında ortaya çıkan e-kitap kavramının (Henke,2001) tanımına ilişkin alan yazında fikir birliğine varılamamış, buna bağlı olarak bir kavram karmaşasının oluşmuştur (Rukancı ve Anameriç, 2003; Bozkurt ve Bozkaya, 2013; Önder, 2011; Shiratuddin ve ark., 2003). E-kitaplarda, basılı kitaplarda olduğu gibi bir gruplama olamaması ortak bir tanıma ulaşmayı güçleştirmiştir.

En genel tanımıyla e-kitaplar Cambridge Sözlüğü (2018)'nde, internette veya diskte, kısacası elektronik ortamda yayınlanan ve kâğıda basılmamış kitap olarak tanımlanmaktadır. Bozkurt ve Bozkaya (2013) da benzer bir biçimde e-kitapları, dijital ortamda ya da basılı kitapların elektronik formatlara aktarılmasıyla oluşturulan ve bir elektronik araç aracıllğıyla kullanılabilen sayısal kitaplardır olarak tanımlamaktadır. Öngöz (2011) ise e-kitapları tanımlarken birçok yazınsal bilgiyi muhafaza eden yapısını vurgulamış ve okuyucunun metinler arasında dolaşabileceği nitelikte düzenlenmiş, taşınabilir donanım ve yazılım özelliklerine sahip bir sistem olarak ele almıştır. Önder (2010) ise benzer bir şekilde e-kitapları tanımlamış olmakla birlikte e-kitapların farklı özelliklerini de tanımına eklemiştir. Bu tanımda e-kitaplar "bir ya da birkaç basıl kitabın sayısallaştırlmasıyla elde edilen ya da bütünüyle elektronik ortamda üretilen bir içeriğin, bir masaüstü bilgisayar, ekeran bulunan herbangi bir elde taşınabilir aygit veya özel tasarlanmış bir elektronik kitap okuyucu donanmmda görüntülenebilir, erişilebilir, yayınlanabilir şekilde bulunan ve kullanulan yaz̨lımla sağlanan žengin metin özellikleri ile (kitap ayracu ekleme, metin işaretleme, not alma gibi) geleneksel okuma surasinda yapulan işlevlerin de gerçeklesstirilebildiğ elektronik. 
biçim” (Önder, 2010, ss. 33) olarak ifade edilmiştir. Böylelikle Önder (2011) e-kitapların, bireylerin basılı kitapları okuma esnasındaki yaşam deneyimlerini de içerdiğinin altını çizmiştir. Teknolojik gelişmeler göz önüne alındığında araştırmacıların e-kitap tanımlarında da değişimler gözlemlenmektedir. Kaya (2013) e-kitapları, bilgisayar veya elektronik ortamlarda okunmak için tasarlanmalarının ve basılı olmadıkları halde basılı kitapların bütün özelliklerini taşımalarının yanı sıra; ses, görüntü, video, çoklu ortam öğeleri ile etkileşimli bağlantıları içeren taşınabilir kitap biçimi şeklinde tanımlayarak bu kavramı genişletmiştir. Zaman içerisinde e-kitaplar eğitim ortamlarında da yerini almış ve bu durum eğitim ortamlarındaki e-kitaplara ilişkin tanımların ortaya çıkmasına neden olmuştur. Bu tanımlamalardan birinde e-kitaplar, sınıf ortamında öğrenci-öğretmen etkileşimini arttıran öğrenme-öğretme sürecinin önemli bir parçası olan ve olumlu sonuçların ortaya çıkmasını sağlamaya aday materyaller olarak ifade edilmektedir (Öngöz, 2011).

E-kitapların başlangıçta ders kitapları ve yetişkin okuma kitapları şeklinde toplumsal hayata dahil olmasına bağlı olarak e-kitap tanımlamalarında "özel” bir alan olan çocuğa ilişkin bulgulara tam olarak rastlanmamaktadır. Tanımlardan da anlaşıldığı üzere e-kitapların ilk oluşumları betimlenmemiş ve gelişimsel bir süreçten söz edilmeksizin sadece genel bir tanım yapılmıştır. Ancak çocuklara yönelik e-kitapların yaygınlaşması farklı bir e-kitap tanımını da beraberinde getirmiştir. Yalçıntaş-Sezgin ve Ulus (2017) e-kitapları, 3-8 yaş arası çocuklar için yazılı bir metin, ağız okuması içeren bir interaktif hikâye (ifade), müzik, ses efektleri, hareketli resimler ve şekiller içeren, multimedya efektleri olan, 'yaşayan bir kitap, konuşan kitap ya da CD-ROM hikayeleri' olarak adlandırılan etkileşimli bir hikâye formu olarak tanımlamıştır.

Sonuç olarak e-kitapları; elektronik ders kitapları, elektronik genç kitapları, elektronik yetişkin kitapları, resimli elektronik kitaplar gibi sinıflamalar yaparak ve teknolojik gelişmeler göz önünde bulundurularak tanımlamanın bu kavramın tanımına ilişkin alan yazında fikir birliğine varılmasında kolaylık sağlayacağı düşünülmektedir. Çocuk edebiyatının geldiği son noktalardan biri olan okul öncesi dönem resimli e-kitaplarını gelişimsel bir bakış açısıyla inceleyen bu çalışmada resimli ekitaplar, 3-6 yaş arası çocuklar için elektronik ortamda oluşturulmuş ya da elektronik ortama aktarılmış işitsel ve görsel efektler, çoklu ortam öğeleri ile etkileşim kurmaya olanak veren, hem yetişkinle hem de yetişkin olmaksızın çocuğa eğlenceli kitap okuma aktivitesi sağlayan ve elektronik bir cihaz aracıllğıyla görüntülenebilen çocuğun gelişim alanlarını destekleyici zengin metin kaynaklarıdır. $\mathrm{Bu}$ tanımlamaların kavramın tarihsel sürecinden bağımsız olarak değerlendirilemeyeceği göz önünde bulundurulduğunda e-kitapların kısa bir tarihçesine değinilmesinin önemli olduğu düşünülmektedir. 


\section{E-Kitap Tarihçesi}

Teknolojik gelişmeler ile yazılı basımın gelişmesinde bir dönüm noktası olan Johann Gutenberg’in matbaası yerini farklı teknolojilere bırakmaya başlamıştır (Rukancı ve Anameriç, 2003; Atılgan, 2006; Bozkurt ve Bozkaya, 2013). Alan Kay, 1960 yılında yayınladığ1 "Dynabook" adlı kitabında ilk kez e-kitapların fiilen gelişimini ele almış olmakla birlikte (Rukancı ve Anameriç, 2003) Gutenberg'in adı yıllar sonra farklı teknolojilerden biri olan elektronik kitapların ortaya çıkısıyla tekrar gündeme gelmiştir. 1971 yllında Michael Hart, Gutenberg projesi kapsamında elektronik kütüphane oluşturmak amacıyla ilk elektronik kitabı dijital ortamda yayınlamıştır (Hart, 1992). Böylelikle dünyanın her yerinden okuyucuların kitaplara elektronik ortamda ve ücretsiz olarak ulaşmalarına imkan vererek yeni bir sayfa açmıştır.

1987 yılında ilk hipermetin kurgu çalışmasını disket olarak yayınlanmıştır.1990 yılında Serendipity Systems'in kurucusu John Galuskza, PCBook adlı bir e-book ekran programı oluşturmuştur (The Guardian, 2002). E-kitapların yaygınlaşması ticarileşmesinin de önünü açmıştır. Bu nedenle 1993 yılında BiblioBytes internet üzerinden e-kitaplar satmak için bir web sitesi açan ve ağ için bir finansal değişim sistemi yaratan ilk şirket olmuştur. Roy Hoy, özel olarak e-kitaplar üretmek için "The Fiction Works” yayın şirketini 1994 yılında kurmuştur (The Guardian, 2002). Bu süreçler e-kitapların yaygınlaşmasında önemli tarihsel basamaklar olarak görülmektedir.

E-kitabın yaygınlaşması ile birlikte okuma aktivitesi sırasında okuyucunun PC'ye bağımlı oluşu bir sınırlılık olarak görülmektedir. Bu sinırlılıklar 1998 yılında NuroMedia tarafından e-kitapların PC'den indirilmesine izin veren ilk el bilgisayar okuyucusu olan Roket'i piyasaya sunulması ve SoftBook deri kapaklı telefon tabanlı katalog sistemi ile ortadan kaldırılmaya çalışılmış (The Guardian, 2002) ve bu durum e-kitapların hayatın içine daha çok girmesine olanak sağlamıştır.

1999 yılında Amerikalı yayıncı Simon ve Schuster ibooks'u oluşturarak ilk ticari yayıncı olmuştur. 2000’li yıllarda e-book okuyucuları, yazılımları Frankfurt Kitap Fuarı'nda e-kitap ödülleri düzenleniştir. E-kitaplar gündelik hayatta yerini almaya başlamakla birlikte okuyuculara geleneksel okuma alışkanlıkları elektronik ortama aktarılması için Gemstar, yeni el tipi e-kitap okuyucuları olan RCA ve RED 1100'ü piyasaya sürmüştür (The Guardian, 2002). Aynı dönemde dünyaca ünlü Sony, Apple, Philips, HP, Microsoft vb. şirketler elektronik kitap okuyucu donanımları ve yazılımları geliştirmiştir (Önder, 2011). En önemli e-book okuyucularından biri ise 2007 yllında dünyanın en büyük çevrimiçi kitap perakendecisi olan Amazon.com tarafindan çıkartılan "Kindle" isimli okuyucu olmuştur (Soydan, 2012). 
Türkiye'deki durum incelendiğinde ise 90'lı y1lların sonunda dünyada büyük ilgi gören e-kitaplar Türkiye'de de ilgi görmeye başlamış ve 1995 yılından sonra biçim, ağırlık gibi fiziksel ve bellek kapasitesi, yazılım gibi teknolojik özelliklerindeki gelişmeler ile değişime uğramıştır (Önder, 2011; Öngöz, 2011; Soydan, 2012). Ayrıntılı incelendiğinde 1997 yllında ilk kez Ali Rıza Esin’in “41 Derece" isimli şïr kitabı elektronik ortamda yayınlandığı görülmektedir. Bu gelişmenin ardından 2000 yllında altKitap, ücretsiz, olarak e-kitap yayınlayan ilk çevrimiçi yayınevi olmuştur (Dijital Yayıncılık, 2013). 2001 ve 2002 yıllarında ülkemizde Bilgi Yayınevi tarafından "e-kitap 2001 Roman Yarışması" ve "e-kitap 2002 Öykü Yarışması” (Türkiye'nin ilk elektronik kitap yarışması, 2002); 2003 y1lına gelindiğinde ise “e-kitap 2003 Şiir Yarışması” organize edilmiştir (Dijital Yayıncılık, 2013). Bu yarışmalar e-kitapların edebiyat dünyasına ve okuyuculara tanıtılması ve yaygınlaştırılması bakımından oldukça önemlidir.

2000’li yıllara gelindiğinde geleneksel okuma alışkanlıklarını elektronik ortama aktarılmaya başlanması ile e-kitap satışı yapan e-yayınevlerinin kurulması, gelişmiş fiziksel ve teknolojik özellikleri barındıran okuyucu donanımların satışa çıkması, standartlaşma, dijital haklar ve telif hakları konularında yasal çalışmaların artması gibi gelişmelerin yaşanmasına olanak sağlamıştır (Önder, 2011). Dünyada Kindle ile başlayan devrim Türkiye'de Idefix’in 2010 y1lında yirmi Türk yayıncı ile anlaşması ve mobil cihazlar için uygulamalar sunması ile yaşanmıştır (Soydan, 2012). Bu durum aslında yayınevleri arasında olan rekabet ortamının artık teknolojik bir ortama taşınmasına sebep olmuştur. Böylelikle yeni donanımlar ve yazılımlar geliştirilerek daha fazla okuyucuya ulaşmaya çalışılmıştır. Türkiye'deki donanımlar ele alındığında ise ilk e-kitap okuyucu donanımı olan Walkbook’un Uğur Bilgi Teknolojileri (UBİT) tarafindan 2007 yılında satışa sunulduğu (akt. Alpkıray ve Samur, 2017) ve 2009 yılında ilk Türkçe e-kitap veri tabanı olan Hiperkitap veri tabanı oluşturulmuştur (Dijital Yayıncllı, 2013). Türkiye'de e-kitapların özellikle eğitim-öğretim sektöründe yaygınlaştı̆̆1 görülmektedir. Bu alanda atılan en önemli adımlar ise, Fırsatları Arttırma ve Teknolojiyi İyileştirme Hareketi (FATİH) projesi kapsamında Milli Eğitim Bakanlığının (MEB) ve Anadolu Üniversitesi, Açık Öğretim Fakültesi tarafından atılmıştır. FATİH proje kapsamında MEB 15 milyon öğrenciye; Anadolu Üniversitesi her yıl yaklaşık 5 milyon kitap ile 1,3 milyon öğrenciye e-kitap ulaştırmaktadır (Bozkurt ve Bozkaya, 2013; Mutlu, Korkut ve Yılmaz, 2006).

Sonuç olarak, Gutenberg Projesi ile birçok bilginin az maliyetle bilgisayar ortamında muhafaza edilebildiği ve paylaşılabildiği gösterilmiştir. Başlangıçta akademik çevrelerde tercih edilen elektronik dergi ve e-kitaplar, zaman içerisinde alternatif bir yayıncıllk sektörü haline gelmiştir (Rukancı ve Anameriç, 2003). Gelişen yeni teknolojiler ve kodlama dillerindeki ilerlemelerle ekitapların evrime uğramış ve etkileşimli e-kitaplar telefonlarda, bilgisayarlarda veya bulut teknolojisi 
(Cloud computing) ile istenilen her an ve her yerde ulaşılabilir duruma gelmiştir (Bozkurt ve Bozkaya, 2013). Ancak basılı kitaplarla nazaran elektronik kitabın tarihi henüz çok daha kısa ve yakın tarihlidir. Yine de, dijital ortamda mevcut olan ve internet üzerinden dağıtılan elektronik kitaplar bir devrim anlamına gelmektedir (Živković, 2008).

\section{E-Kitabın Özellikleri ve Resimli E-Kitaplar}

Tarihsel süreç incelendiğinde e-kitapların başlangıçta basılı kitapların elektronik ortama aktarılmış versiyonları olduğu görülmektedir (Bozkurt ve Bozkaya, 2013; Mutlu, Korkut ve Yılmaz, 2006). Süreç içerisinde e-kitaplar metin arama ve işaretleme, dipnot oluşturma gibi özelliklerin eklenmesi ve PC'den telefonlara ya da taşınabilir cihazlara aktarılması ile basılı kitaplar ile aynı özellikleri içermeye başlamıştır. Bu süreçte basılı kitaplardan tek farkı bir cihazın bir evdeki büyük bir kütüphaneden daha fazla kitabı muhafaza etme etmesidir. Ancak teknolojik gelişmeler e-kitaplara farklı özelliklerin eklenmesine olanak sağlamıştır (Işs1k, 2013; Kaya, 2013; Mutlu, Korkut ve Yılmaz, 2006; Naranjo-Bock, 2011a; Önder, 2010). E-kitap uygulamalar1, bas1lı kitapların sayısal ortama taşınmasının çok daha ötesindedir (Ersan, 2016). E-kitapların en önemli özelliklerinden biri basılı kitaplar ile kıyaslandığında okuyucu ile etkileșimi daha fazla olmasıdır (Daş, Yıldırım, Bölen ve Çeliker, 2013). Konu resimli çocuk kitapları olduğunda ise etkileșime yönelik özellikler çocuklar için daha dikkat çekici bir unsur olmaktadır.

Buckleitner (2013) ve Bircher (2012)'in araştırmalarında nitelikli bir e-kitap uygulamasının özelliklerinden bahsetmiştir. Buna göre; zengin bir içeriğin olması, kolay kullanım özelliğine sahip olması, kullanıcıya kontrol etme hissi vermesi, öğrenme deneyimi sağlaması, gerektiğinde bilgiye kolayca erişilebilmesi ve etik açıdan uygun olması gerekmektedir. Bu özellikler çocuk kitapları için sırasıyla incelenmesi gerekirse, resimli e-kitapların zengin bir içeriğe sahip olması çok önemlidir. Durağan ve basılı olan kitaplara mikrofon, kamera, hareket algilayıcısı özellikler ve ses, hareket, etkileşim ve oyun getirerek zengin bir öğrenme deneyimi sağlayabilmektedir (Ersan, 2016; Sayer, 2013; Soydan 2012). Ancak çocuklara yönelik bu uygulamalarda içerik ve etkileşimli öğelerde içerik zenginleştirilip canlı renkler tercih edilirken, bu düzenlemelerin ve öğelerin nasıl bir araya getirildiğine bağlı olarak harika bir e-kitaplar ortaya çıkabilir ya da bu e-kitaplar hayal kırıklığına ve karışılığa neden olabilir (Naranjo-Bock, 2011a). Bu nedenle uygulamadaki etkileşimli öğeler, hareketli görüntüler, müzik ve diğer sesler rahatsız edici değil, kolayca erişilebilir ve eğlenceli olmalıdır (Ersan, 2016).

Çocuklara hitap eden e-kitaplar yaş aralığına göre incelendiğinde özellikleri bakımından değişkenlik gösterdiği görülmektedir. Öncelikli olarak çocuklara yönelik kitap uygulamaları, basılı kitaplarda 
olduğu gibi hikâyenin kavramsal altyapısı ile görsel ya da işitsel efektleri uyumlu olacak şekilde tasarlanmalıdır (Bircher, 2012; Buckleitner, 2013). En önemli özelliklerden biri resimli e-kitaplarda yazılı talimatların yok denecek kadar az olmasıdır. Okumayı bilmeyen bir kitle için yönergeler olabildiğince basitleştirilip görselleştirilmektedir. Bazı durumlarda ise sözlü yönergeler çocuğu uygulama esnasında yönlendirmektedir. Bununla birlikte çocuklar için tasarlanan resimli e-kitap uygulamaları, hikâye kitabı ve oyun özelliklerini de içinde barındırmaktadır. Bu sayede uygulama daha ilgi çekici hale getirilmektedir

Resimli e-kitaplar genellikle her ortama ya da kişiye göre uyarlanabilme özelliğine sahiptir. Uygulama esnasında hikâyenin uygulama tarafindan seslendirilmesi ya da kullanıcı tarafindan okunması, ses efektlerinin açılması ya da kapatılması, sayfaların uygulama tarafindan yönlendirilmesi ya da kullanıcı tarafından yönlendirilmesi gibi seçenekleri içinde barındırabilmektedir. Resimli ekitapların sunduğu en önemli özelliklerden biri de ebeveynlere, e-kitap seçme sürecine ilişkin kitaba yönelik olarak; kitabın aldığı ödülleri, alternatif uygulamaları ve diğer kullanıcılar tarafindan kitapla ilgili yorumları görme fırsatı sunmasıdır. Böylelikle ailenin seçim yapma aşaması daha sağlıklı ve güvenilir hale gelebilmektedir. Ancak her ne kadar ebeveynlere seçim kolaylığ1 sunsa da bu uygulamaların da etik değerlere uygun olması gerekmektedir. Uygulamanın makul bir fiyat ile satışa sunulması uygulama içinde ticari linklerin çocukların kolaylıkla ve/veya yanlışlıkla tuşlayabileceği bölümlerde olmaması gerekmektedir.

\section{E-Kitapların Olumlu ve Olumsuz Özellikleri}

Kullanım kolaylığı, maliyetinin düşüklüğü ve erişilebilirlik açısından resimli e-kitaplar gittikçe yaygınlaşmaktadır (Alpkıray ve Samur, 2017; Önder, 2011). Uygulamaların çoğunun ücretsiz olması ebeveynlere internet aracıllğ̆1yla çocuğuna bir e-kütüphane oluşturabilme fırsatı sunmaktadır (Gönen ve Balat, 2002). Günümüzde sosyoekonomik düzeyden bağımsız şekilde birçok kişide ekitap okuyabilecek özelliklere sahip akıllı telefonların bulunduğu ve internete erişim sağlandığ1 rahatlıkla söylenebilir. Bu nedenle bir bakıma resimli e-kitaplar, çocukların resimli kitaplara ulaşımının önündeki sosyoekonomik düzey engelini nispeten aza indirebilir.

Resimli e-kitapların çocuğun gelişim açısından sahip olduğu olumlu özelliklere bakıldığında uygulama içerisinde metnin boyutların ayarlanabilir olması olumlu özelliklerden biri olarak ele alınabilir. Okul öncesi dönemde çocuklar kelimelerden önce harfleri okumaya başlamaktadırlar. Naranjo-Bock (2011b), okumayı yeni öğrenmiş veya okumayı bilmeyen çocuklar için harf boyutlarının ayarlanabilir olduğu e-kitap uygulamalarının çocuğun gelişimini destekleyebileceğini belirtmektedir. Dolayısıyla okul öncesi dönemde çocukların erken okuryazarlık becerilerini 
geliştirmede e-kitaplara kayda değer bir önem atfedilmektedir(Yalçıntaş-Sezgin ve Ulus, 2017). Diğer taraftan e-kitap okuyabilmek, farklı teknolojik araçları etkin kullanabilme becerisini de gerektirmektedir. Bu yönüyle çocuklar, eş zamanlı olarak bu araçları kullanma becerisini geliştirmektedir (Işı1k, 2013). Bununla birlikte okul öncesi dönem çocukları için resimli e-kitaplar harekete geçirici mesajlar sağlayan simgeler ve görüntüler aracillğıyla çocuğun dikkat ve ilgisini sürdürmenin yanı sıra yetişkin olmaksızın çocuğun kitapla etkileşim kurmasına olanak sağlamaktadır (Gönen ve Balat, 2002; Iş1k, 2013; Naranjo-Bock, 2011a). Böylelikle çocuk bir yetişkin gerekmeksizin okumaya yönelebilmektedir. Belki de resimli e-kitapların en önemli özelliklerinden biri çocuğa bağımsız kitap okuma alanı sağlamasıdır.

Elektronik kitaplar birçok olumlu özelliğe sahip olmakla birlikte çeşitli olumsuz özellikleri de içinde barındırmaktadır. Resimli e-kitapların en büyük olumsuz özelliği yalnızca elektronik ortamda kullanılabilmesidir (Soydan 2012). Bu durum en bașta kullanılan cihazın şarjı bittiğinde uygulamanın sona ermesi gibi bir olumsuz özelliği de beraberinde getirmektedir. Bununla birlikte teknolojik cihazlar aracılı̆̆ıyla kullanılması cihazın bozulması ya da çocuklar tarafından düşürülerek kırılması gibi problemler de ortaya çıkabilmektedir. Bununla birlikte çocuklar her şeyin tadına bakma eğilimindeyken bu dönem için oluşturulan uygulamaların basılı kitapların özelliklerini tam olarak içinde barındırılmaması da yine başka bir olumsuz özellik olarak ele alınmaktadır (Sayer, 2013). Bunun yanı sıra teknolojik bir cihazı çocuğun ağzına alma olasılığı da başka bir tartışma konusudur.

Diğer taraftan e-kitap endüstrisinde henüz uluslararası standardın olmaması birbirine uymayan formatlarda e-kitapların üretilmesine sebep olmaktadır. Bu durum nitelikli bir e-kitabın piyasaya sürülmesi ve ulaşılabilir olması bakımından bir engeldir (Öngöz, 2011). Bununla birlikte e-kitaplar bir yatırım değeri taşımaktadır. Buna bağlı olarak bu uygulamalarda çocuklara reklamlar sunulabilmektedir. Bu reklamların çocuğa uygunluğu ise bir diğer tartışma konusudur. Ancak asıl tartışma konusu ise çocukların bu kitapları bir ekran üzerinden okuyor olmalarıdır. Çocukların ekranla ilişkisinin nasıl olması gerektiğine yönelik birçok tartısmanın bulunduğu bu dönemde bu haklı bir endişedir. Özellikle okul öncesi dönem çocuklarının ekran karşısında uzun süre vakit geçirmesi gelişimsel açıdan bir risk olarak değerlendirilmektedir (Anderson, Gentile ve Buckley, 2007; Gürcan, Özhan ve Uslu, 2008; Kars 2010). Son dönemlerde çocukların ekran maruz kalma yaşının gittikçe düştüğü (Akçay ve Özcebe, 2012) ve ekran başında geçirilen sürenin arttığ1 göz önünde bulundurulduğunda resimli e-kitapların bu süreyi daha da arttırması kaygisıyla yaklaşılmaktadır. 
Alan yazında e-kitaplar ile ilgili yapılan çalssmalar incelendiğinde genellikle eğitim-öğretim ortamlarında ders kitabı ya da materyali olarak kullanılmasına ilişkin çalışmaların yoğunlukta olduğu görülmektedir. Bu çalışmalar e-kitapların olumlu (Barnyak ve McNelly, 2016; Brusilovsky, Chavan ve Farza, 2004; İleri Aydemir, Öztürk ve Horzum, 2013; McFall, 2005; Schwartzman ve Tuttle, 2002) ve olumsuz (Kropman, Schoch ve Teoh, 2010; Lam, Lam, Lam ve McNaught, 2009; Woody, Danie ve Baker, 2010) özelliklerini ortaya koymaktadır. İleri Aydemir, Öztürk ve Horzum (2013) ekran üzerinden okumanın 5. sınıf öğrencilerinin bilgilendirici ve öyküleyici metin türünde okuduğunu anlama düzeylerine etkisini inceleyen çalışmada ekrandan okuyan öğrencilerin okuduğunu anlama düzeylerinin basılı materyalden okuyan öğrencilerinkinden anlamlı derecede yüksek olduğu bulunmuştur. Barnyak ve McNelly(2016)'nin Vygotsky'nin sosyokültürel teorisinden yola çıkarak çocukların okudukları e-kitapların okuma becerileri üzerindeki etkisini incelediği çalışmasında e-kitapların tüm müdahale gruplarında kelime dağarcıklarının geliştirdiğini belirtmiştir. Walton (2007) ise bu görüşlere farklı bir açıdan bakarak e-kitapları basılı kitaplarla kıyaslarken ekitapların hem iyi hem kötü olduklarına yönelik görüş belirtmiştir. Bu görüşte e-kitapların dijital, taşınabilir, arama ve derecelendirme yapmaya uygunluk açısından iyi; gözü yorma, okunma zorluğu ve ekran bağımlılığına yönlendirmesi açısından kötü olarak ifade etmiştir.

Sonuç olarak resimli e-kitaplara ilişkin olumlu ve olumsuz birçok özellik tartışllmakta ve diğer taraftan basılı kitaplarla karşılaştırılması yapılarak daha iyi ya da daha kötü olduğuna veya ekitapların basılı kitapların yerini alıp almayacağına dair tartışmalar devam etmektedir. Ancak bu çalışma kapsamında resimli e-kitaplar teknolojinin gelişmesine bağlı olarak günlük yaşama dâhil olmuş bir zenginlik olarak değerlendirilmekte ve iyi ya da kötü olarak tanımlamaktan ziyade nitelikli ve niteliksiz olma özelliklerini göz önünde bulundurmak ve gelişimsel bir bakış açısı sunmak hedeflenmektedir.

\section{Resimli E-Kitaplara Gelişimsel Bir Bakış}

Çocuk edebiyatı çocuğun gelişimi açısından oldukça işlevseldir. Çocuk edebiyatı; özenle hazırlanmış, hedef kitleye uygun, nitelikli çocuk kitapları çocuğa sunulduğunda gelişime ilişkin söz konusu işlevini yerine getirmektedir. Çocuklar için hazırlanan kitaplar, çocuğun okurken zevk almasına, eğlenirken eğitilmesine, hayal dünyasının ve dil becerilerinin gelişimine katkı sağlamalı ve kitabın hayatındaki yerini kavramasına yardımcı olmalıdır (Sayer, 2013; Temizyürek, 2014; Veziroğlu ve Gönen, 2012).

Son dönemlerde tarihsel süreç içerisindeki gelişmelerin doğal sonuçlarından biri olan teknolojik gelişmelerin çocuk edebiyatı alanına katmış olduğu resimli e-kitapların, çocuğun gelişimi üzerinde 
nasıl bir etkiye sahip olacağı konusu halen açıklığa kavuşmuş değildir. E-kitaplara ilişkin tartışmaların büyük çoğunluğunun e-kitapların basılı kitapların yerini alıp almayacağı, e-kitapların özellikleri, eğitim materyali olarak kullanımı (Alpkıray ve Samur, 2017; Işık, 2013; İleri Aydemir, Öztürk ve Horzum, 2013; Kaya, 2013; Mutlu, Korkut ve Yllmaz, 2006) gibi konular çerçevesinde şekillenirken ve resimli e-kitapların gelişimsel boyutuna ilişkin tartışma ve araştırmaların resimli ekitapların erken okuryazarlık becerilerine, okuma-yazma öğrenimine etkisi gibi sınırlı boyutlarda ele alınmıştır. Buradan hareketle resimli e-kitaplara ilişki gelişimsel boyutun yeterince ele alınmadığ1 düşünülmüş ve medyanın hem yetişkinlerin hem de çocukların hayatına ne denli hızlı etki etiğini göz önünde bulundurarak resimli e-kitaplara ilişkin gelişimsel bir bakış açısı sunulmasına ihtiyaç duyulmuştur.

İnternetin kullanımının yaygınlaşmasıyla daha çok gündeme gelen elektronik yayıncılıkla, çocukların yazı büyüklügünü ayarlayabilecekleri, çoklu ortam özellikleri (ses, video, grafik) ile donatılmış renkli yayınlara, resimli e-kitaplara ulaşabilmeleri daha mümkün hale gelmiştir (Sayer, 2013). Resimli ekitapların bu özellikleri göz önünde bulundurulduğunda içermiş olduğu ses, görüntü efektleri sayesinde çocuğa çeşitli uyaranlar sunmakta ve bu özellikleri çocuklar için kitabı daha ilgi çekici hale getirmektedir. Bunun doğal bir sonucu olarak çocukların kitapla geçirmiş oldukları sürenin uzayabileceği düşünülmektedir. Resimli e-kitaplar, kitap okuma aktivitesi sırasında çocuğa okuyacağı kitabı, yapacağı etkinliği ve oynayacağı oyunu seçme imkânı vermektedir (Takacs, Swart ve Bus, 2015). Resimli e-kitaplar, sahip olduğu diğer (sesli okuma, sesli yönlendirme simgeleri, ses ve görüntü efektleri vb.) araçlar aracıllğ̆yla çocuğa etkileşimli bir kitap okuma deneyimi sunmaktadır. Ancak basılı kitapların çocuğa sağlamış olduğu kitaba dokunma, kitap üzerinde yer alan farklı dokunsal uyaranlara dokunma, sayfa çevirme, kitabın kokusunu alma gibi gerçekçi deneyimleri resimli e-kitaplar sunamamaktadır. Bunun yanı sıra resimli e-kitaplar, okul öncesi dönem çocukları için bir yetişkin olmaksızın kitap okuyamama bağlamında da bir çıkış noktası olmuştur. Elbette bu ifade, okul öncesi dönem çocukları için tek başına elektronik bir araç üzerinden kitap okumanın yetişkin etkileşimli kitap okumanın yerini tutabileceği anlamına gelmemektedir. Burada anlatılmak istenen, yetişkin etkileşimli kitap okuma zamanlarının dışında kitap okumaya ilişkin çocuğa özgür bir alan yaratmasıdır.

E-kitapların gelişimsel açıdan ele alınması gereken önemli bir alan da özel gereksinimli çocuklar için de kullanılabilmesidir. E-kitaplar özel gereksinimli bireyler için özelleştirilebilmektedir (Öngöz, 2011). Örneğin sesli kitaplar, görme engelli çocukların bağımsız olarak kitap okuyabilmesine imkânı vermektedir. Böylelikle özel gereksinimli çocuğun gereksinimine bağlı olarak hayatında meydana gelen sınırlılıkları azaltabilir. E-kitapların önemli bir etkisinin olduğu bir diğer özel gereksinimli grup 
ise, Dikkat Eksikliği ve Hiperaktivite Bozukluğu (DEHB) olan çocuklardır. Resimli e-kitaplar çocuğu basılı kitaplara göre daha aktif bir konumda tutmakta ve işitsel-görsel efektlerle kitabı ilgi çekici hale getirmektedir. Bu durum sayesinde DEHB'li çocukların resimli e-kitaba daha çok odaklanacağ1 ve okunan metni daha rahat anlayacağı düşünülmektedir. Özellikle okunan metne odaklanma ve metni anlama ile ilgili en çok zorluk çeken bir diğer grup ise Özgül Öğrenme Güçlüğü olan çocuklardır. Resimli e-kitapların DEHB’li çocuklarda olduğu gibi Özgül Öğrenme Güçlüğü olan çocuklarda da odaklanma süresini artırması da olasıdır. Hikâye ile ilgili oyunlar ile okunan metni anlama süreci ve erken okuryazarlık becerileri desteklenebilir. Diğer bir özel gereksinimli grup olan Otizm spektrum bozukluğu olan çocuklar için de resimli e-kitapların etkili bir araç olabileceği düşünülmektedir. Uzun süredir teknolojinin Otizm spektrum bozukluğu olan bireyler üzerindeki olumlu etkileri tartışlmaktadır (Akgül, 2016; Ersöz ve Ceylan, 2013; Şenyürek, Yılmaz ve Köse, 2017). Resimli e-kitapların otizmli çocuklar üzerindeki etkisine yönelik alan yazında çalışmaya rastlanamamıştır. Ancak bu kitapların otizmli çocukların etkileşim kurma ve odaklanma üzerinde olumlu etkilerinin olabileceği düşünülmektedir.

Resimli e-kitapların gelişimsel açıdan yukarıda sözü edilen birçok olumlu özelliği olmakla birlikte çocuğun gelişimi açısından soru işareti oluşturabilecek durumlar da söz konusudur. Bunlardan ilki, resimli e-kitapları okurken özellikle okul öncesi dönemdeki çocukların ekrana maruz kalması ve ekran kullanmasıdır. Çocukların ekranla ilişkisinin nasıl olması gerektiğine yönelik birçok tartışmanın bulunduğu bu dönemde bu haklı bir endişedir. Özellikle okul öncesi dönem çocuklarının ekran karşısında uzun süre vakit geçirmesi gelişimsel açıdan bir risk olarak değerlendirilmektedir (Anderson, Gentile ve Buckley, 2007; Gürcan, Özhan ve Uslu, 2008; Kars 2010). Son dönemlerde çocukların ekran maruz kalma yaşının gittikçe düştüğü (Akçay ve Özcebe, 2012) ve ekran başında geçirilen sürenin arttığı göz önünde bulundurulduğunda resimli e-kitapların bu süreyi daha da arttırması kaygısıyla yaklaşılmaktadır. Bu bağlamda resimli e-kitapların uzun süre ekrana bakmayı gerektirmesi buna bağlı olarak çocuklarda göz yorulması ve ekran bağımlılığına ilişkin tartışmaları beraberinde getirmektedir (Walton, 2007). Çocukların ekran kullanım sürelerine ilişkin önceleri çocukların üç yaşına kadar olan dönemde ekrandan tamamen uzak tutulmaları, 3-6 yaş döneminde ekran süresinin günlük yalnızca 20-30 dakika ile sınırlandırılması görüşü hakim olurken (Pedagoji Derneği, 2015), Amerikan Pediatri Akademisi (AAP) (2016) tarafindan çocukların ekran süreleri günümüz koşullarına göre yeniden gözden geçirilmiş ve şu şekilde düzenlenerek önerilerde bulunulmuştur: bebekler 18 aylık olana kadar görüntülü konuşma dışında ekrandan uzak tutulmalıdır; 18-24 aylar arasındaki dönemde çocuklarını dijital medya ile tanıştırmak isteyen ebeveynler yalnızca yüksek kaliteli programları tercih etmeli ve çocukların gördüklerini yorumlamalarına yardımcı olmak amacıyla onlarla birlikte izlemelidirler; 2-5 yaş arası dönemde ise 
yalnızca yüksek kaliteli programlar tercih edilmeli ve ekran süresi bir saati geçmemelidir ve ebeveynler çocukların gördüklerini anlamalarına ve dış dünyaya genellemelerine yardımcı olmak için çocuklarıyla birlikte izlemelidirler; 6 yaş ve üzeri çocuklar için medya kullanımı sınırlandırılmalı ve medya kullanımının çocukların yeterli uyku, fiziksel aktivite ve sağlık için gerekli olan diğer davranışların yerini almadığından emin olunmalıdır; ev içerisinde yatak odası gibi medya araçlarının bulunmadığı bölümlerin yanı sıra akşam yemeği ya da yolculuklar gibi medya kullanımı olmaksızın birlikte zaman geçirilecek alanlar yaratılmalıdır ve son olarak çevrim içi ve çevrim dışı diğerlerinden gelebilecek tehditleri içeren durumlarla ilgili olarak sürekli olarak güvenlikten emin olunmalıdır. Söz konusu bu öneriler Amerikan Psikoloji Derneği (APA) (2019) tarafından da desteklenmiş ve konu edinilmiştir. Çocukların ekran sürelerine ilişkin söz konusu olan bu yeniden gözden geçerimeler göstermektedir ki günümüz koşullarında çocukların tamamen ekrandan uzak tutulması mümkün değildir. Bunun yanı sıra özellikle çocukların ekran karşısında geçirdikleri sürelerin kısıtlı tutulmasına ve bu kısıtlı sürenin de ebeveyn gözetiminde ve kaliteli yayınlarla değerlendirilmesi gerektiğine vurgu yapılmaktadır. Dolayısıyla çocuklar için halihazırda kısıtlı olması gereken sürenin resimli e-kitaplar aracılığılla daha zengin ve aktif bir şekilde geçirilmesi sağlanabilir.

Genel olarak çocuk edebiyatı, çocukların dil gelişimini kolaylaştırmaktadır. Bu nedenle konu ile ilgili ne kadar çok ortam sunulursa o denli dil öğreniminde başar1 elde edilecektir (Aytaş, 2003). Özellikle son yıllarda erken okuryazarlık becerileri gittikçe önem kazanmıştır. Teknolojik gelişmelere bağlı olarak erken okuryazarlık becerilerinin desteklenmesinde resimli elektronik kitaplar bir araç olarak kullanılmaya başlanmıştır (Yalçıntaş-Sezgin ve Ulus, 2017). Yapılan araştırmalar resimli e-kitapların erken okuryazarlık becerilerini desteklediğini ortaya koymuştur (Shamir ve Korat, 2015; Penuel ve ark., 2009). İlerleyen süreçte ise, e-kitaplar çocukların yazı farkındalığı, sözcük tanınma ve kelime okuma becerilerini geliştirmekte ve kelime dağarcığını zenginleştirmektedir (Korat ve Shamir, 2008; Korat, 2010, Korat ve Drori, 2016).

Resimli e-kitaplar yukarıda ifade edilen tüm gelişimsel bakış açısı çerçevesinde değerlendirildiğinde resimli e-kitaplara gelişimsel açıdan ön yargılı bakılmaması gerektiği düşünülmektedir.

\section{SONUÇ}

Tarihsel süreç içerisinde meydana gelmiş olan çoğu yenilik başlang1çta büyük bir endişe ve önyarg1 ile karşılaşmıştır. Çoğu zaman bu bilinmeyene karşı verilen bir tepki şeklinde olmuştur. Benzer bir durum resimli e-kitaplar için de söz konusu olmuştur. Bu kaygıların başında da resimli e-kitaplar basılı kitapların yerini alacak mı sorusu gelmektedir. Ancak alan yazın ve gelişimsel bilgiler ışığında konu değerlendirildiğinde, konuya bu denli önyargılı yaklaşmaya gerek olmadığ1 düşünülmektedir. 
Nasıl ki basılı resimli çocuk kitaplarında nitelikli ve niteliksiz eserler bir arada bulunabildiği gibi resimli e-kitaplarda da benzer bir durum söz konusudur. Aslında tartışılması gereken esas konu nitelikli resimli e-kitapların özellikleri, kitap seçiminde dikkat edilmesi gerekenler ve çocukların resimli e-kitaplar ile ne kadar süre vakit geçirecekleri olmalıdır.

Yapılan araştırma kapsamında resimli e-kitapların çocukların gelişimine katkı sağlayabilmesi için öncelikli olarak içeriğinin çocuğun yaş ve gelişim düzeyine uygun olmakla beraber; çocukların ilgisini çekebilecek çoklu ortam öğelerine (ses, görüntü, renk, metin boyutu efektleri vb.) sahip olması, yetişkinle okunabildiği gibi (sesli okuma sisteminin kapatılmasına imkan vermesi) çocuğun tek başına kitap okuma (sesli anlatım özelliğine sahip) deneyimine imkan vermesi, okunan metnin daha iyi anlaşılabilmesi için çeşitli küçük oyunları içerisinde barındırması, çocukların yaş ve gelişim düzeylerine göre risk oluşturabilecek reklamların ortaya çıkmasını engelleyen bir denetim mekanizmasına sahip olması, özel gereksinimli bireyler için uyarlamalara imkan veren çeşitliliğe sahip olması ve en önemlisi ekran kullanım süresinin yetişkin tarafindan denetlenmesi gerektiği düşünülmektedir. Özellikle ekran kullanım süresi, çocuğun kitap okuyor olması gerekçesi ile çocuğun gelişim düzeyine uygun olmayan sürelere ulaşmamalıdır. Tüm bu bilgiler 1şığında sonuç olarak araştırmacılar tarafından resimli e-kitaplar bir çeşitlilik ve zenginlik olarak değerlendirilmekte ve basılı kitapların yerini alması endişenin bir kenara bırakılarak alternatif bir seçenek olarak değerlendirilmesi gerektiği düşünülmektedir.

Son olarak; söz konusu kayg1 ve endişelerin azalması, nitelikli resimli e-kitapların özelliklerinin anlaşılabilmesi, ebeveynlere bu kitapları nasıl seçebileceklerine ilişkin rehberlik edilebilmesi ve en önemlisi resimli e-kitapların çocukların gelişimine katkı sağlayabilecek şekilde nasıl kullanılacağının anlaşılabilmesi için resimli e-kitaplara yönelik gelişimsel bakış açısına sahip daha çok araştırma yapılmasına ihtiyaç duyulmaktadır.

\section{KAYNAKÇA}

Akçay, D., ve Özcebe, H. (2012). Okul öncesi eğitim alan çocukların ve ailelerinin bilgisayar oyunu oynama alışkanlıklarının değerlendirilmesi. Çocuk Dergisi, 12(2), 66-71.

Akgül, E. M. (2016). Autism, technology, and prospective special education teachers. FSM İlmî Arastırmalar Insan ve Toplum Bilimleri Dergisi, 8, 25-34.

Aktaş Arnas, Y. (2005). 3-18 Yaş grubu çocuk ve gençlerin interaktif iletişim araçlarını kullanma alışkanlıklarının değerlendirilmesi. TOJET: The Turkish Online Journal of Educational Technology, 4(4), 59. 
Alpkiray, F. ve Samur, Y. (2017). A content analysis of thesis and dissertations published in Turkey on electronic books. SDU International Journal of Educational Studies, 4(1), 12-28.

Amerikan Pediatri Akademisi (2016). Amer_can academy of pediatrics announces new recommendations for children's media use içinde. Erişim adresi: https://www.aap.org/enus/about-the-aap/aap-press-room/Pages/American-Academy-of-Pediatrics-AnnouncesNew-Recommendations-for-Childrens-Media-Use.aspx.

Amerikan Psikoloji Derneği (2019). Digital Guidelines: Promoting Healthy Technology Use for Children içinde. Erişim adresi: https://www.apa.org/helpcenter/digital-guidelines.aspx.

Anderson, C. A., Gentile, D. A., ve Buckley, K. E. (2007). Violent video game effects on children and adolescents: Theory, research, and public policy. New York: Oxford University Press.

Atılgan, D. (2006) "İletişim teknolojileri çağında değişen bilgi hizmetleri”, I.Uluslararası Bilgi Hizmetleri Sempozyumu, 25-26 Mayıs 2006, İstanbul: İstanbul Üniversitesi.

Barnyak, N. C., ve McNelly, T. A. (2016). The literacy skills and motivation to read of children enrolled in Title I: A comparison of electronic and print nonfiction books. Early Childhood Education Journal, 44(5), 527-536.

Bircher, K. (2012). What makes a good picture book app. The Horn Book Magazine, 88(2), 72.

Bozkurt, A., ve Bozkaya, M. (2013). Etkileşimli e-kitap: Dünü, bugünü ve yarını. Akademik Bilişim 2013, 375-381.

Börekçi, G. (2016). Dünyanın 1658 tarihli ilk çocuk kitabı. Erişim Adresi: https://egoistokur.com/1658-tarihli-ilk-cocuk-kitabi-egoist-okurda/.

Brusilovsky, P., Chavan, G., ve Farzan, R. (2004). Social adaptive navigation support for open corpus electronic textbooks. In International Conference on Adaptive Hypermedia and Adaptive Web-Based Systems (pp. 24-33). Springer, Berlin, Heidelberg.

Buckleitner, W. (2013). The Art and the Science of the Children's eBook. Children's Technology Review. $7-9$.

Cambridge Dictionary (2018). Definition of E-Book içinde. Erişim adresi: http://www.merriamwebster.com/dictionary/book.

Çakmak-Güleç, H. ve Kanat-soysal, Ö. (2018). Okul öncesi dönem çocuk kitaplarının tarihçesi. A. Turla (Ed.) Cocuk Edebiyatı (ss.40-49). Ankara: Hedef CS Basın Yayın.

Dağlıoğlu, H. E., ve Çakmak, Ö. Ç. (2009). Okul öncesi çocuklarına yönelik yayınlanan hikâye kitaplarının şiddet ve korku öğeleri açısından incelenmesi. Türk Kütüphanecilĭgi, 23(3), 510534.

Daş, A., Yıldırım, G., Bölen, M. C., ve Çeliker, O. (2013). Etkileşimli e-kitapların tasarım aşamalarının incelenmesi ve tasarım farklılıklarının belirlenmesi. Erişim Adresi: https://ab.org.tr/ab13/bildiri/58.pdf. 
Dijital Yayıncılık, (2013). Türkiye'de e-kitap. Erişim Adresi: http://www.xn--dijitalyaynclkfgccb.com/etiket/e-kitap/.

Ersan, M. (2014). Tablet ortamında resimli cocuk kitaplari; biçim ve içerik özellikleri üzerine bir inceleme (Yüksek Lisans Tezi). Hacettepe Üniversitesi Güzel Sanatlar Enstitüsü, Ankara.

Ersan, M. (2016). Tablet ortamında resimli çocuk kitapları; biçim ve içerik özellikleri üzerine bir inceleme. The Turkish Online Journal of Design, Art and Communication, 6(2), 148-158.

Ersöz, A. ve Ceylan, M. (2013). Bilişim teknolojilerinin otizm spektrum bozukluğunun tedavisinde kullanımı. Erișim

Adresi: https://www.researchgate.net/profile/Alpaslan_Ersoez/publication/259849659_Using_ Information_Technologies_for_Treatment_of_Autism_Spectrum_Disorders/links/0046 352e23b23d3a30000000.pdf.

Gökmen, B. (2017). Ödüllï çocuk edebiyatı yapıtlarmın çocuk edebiyatının temel öğeleri bakımından incelenmesi (Yayınlanmamış Yüksek Lisans Tezi). Ankara Üniversitesi Eğitim Bilimleri Enstitüsü, Ankara.

Gönen, M. (2011). Türkiye'de okulöncesi çocuk edebiyat1. Erişim Adresi: http://panel.unicef.org.tr/vera/app/var/files/t/u/turkiye $\%$ E2\%80\%99de-okul-oncesicocuk-edebiyati.pdf

Gönen, M., ve Balat, G. U. (2002). Çocuk kitaplarına yeni bir yaklaşım: İnternet’te resimli çocuk kitaplar1. Türk kütü̈paneciliği, 16(2), 163-170.

Gönen, M., Karakuş, H., Uysal, H., Kehci, A., Ulutaş, Z., ve Kahve, Ö. (2016). Resimli çocuk kitaplarının içerik ve resimleme özelliklerinin bazı değişkenler açısından incelenmesi. Hacettepe Üniversitesi Ë̆itim Fakültesi Dergisi, 31(4), 724-735.

Gönen, M., Uludağ, G., Tanrıbuyurdu, E. F., ve Tüfekçi, E. (2014). 0-3 Yaş çocuklarına yönelik resimli çocuk kitaplarının özelliklerinin incelenmesi. Hacettepe Üniversitesi Eğitim Fakültesi Dergisi, 29(1), 126-139.

Güleç-Çakmak, H. G., ve Gönen-Sofuoğlu, M. (1997). 1974-1993 yılları arasında Türkçe basılmış olan resimli öykü kitaplarının resimlendirilme ve fiziksel özellikleri yönünden incelenmesi. Türk Kütüphanecilï̌i, 11(1), 42-53.

Gürcan, A., Özhan, S., ve Uslu, R. (2008). Dijital oyunlar ve cocuklar üzerindeki etkileri. Ankara: Başbakanlık Aile ve Sosyal Araştırmalar Genel Müdürlügü Yayınları.

Hart, M. (1992). The history and philosophy of project gutenberg by Michael Hart: Project Gutenberg. Erişim Adresi: http://www.gutenberg.org/wiki/Gutenberg:The_History_and_Philosophy_of_Project_ Gutenberg_by_Michael_Hart.

Henke, H. (2001) Electronic Books and ePublishing. London: Springer-Verlag.

Ihmeideh, F. M. (2014). The effect of electronic books on enhancing emergent literacy skills of pre-school children. Computers ve Education, 79, 40-48. 
Işık, A. D. (2013). Elektronik kitapların eğitimde kullanılabilirliği (Usability of E-Books in Education). Bartm Üniversitesi Eğitim Fakültesi Dergisi, 2(2), 395-411.

İleri Aydemir, Z., Öztürk, E., ve Horzum, M. B. (2013). Ekrandan okumanın 5. sınıf öğrencilerinin bilgilendirici ve öyküleyici metin türünde okuduğunu anlama düzeylerine etkisi. Kuram ve Uygulamada Ë̈itim Bilimleri, 13(4), 1-14.

Kars, G.B. (2010). Şiddet içerikli bilgisayar oyunlarmın çocuklarda saldırganlüga etkisi. Yayımlanmamıs Yüksek Lisans Tezi. Ankara Üniversitesi, Sağlık Bilimleri Enstitüsü, Ankara.

Kaya, C. B. (2013). 6. smuf sosyal bilgiler dersi için geliştirilen etkileşimli elektronik kitabın ögrenci başarnsı üzerine etkisi (Yayımlanmamış Yüksek Lisans Tezi). Gazi Üniversitesi Eğitim Bilimleri Enstitüsü, Ankara.

Korat, O. (2010).Reading electronic books as a support for vocabulary, story comprehension and word reading in kindergarten and first grade. Computers ve Education 55, 24-31.

Korat, O., ve Segal-Drori, O. (2016). E-book and printed book reading in different contexts as emergent literacy facilitator. Early Education and Development, 27(4), 532-550.

Korat, O., ve Shamir, A. (2008). The educational electronic book as a tool for supporting children's emergent literacy in low versus middle SES groups. Computers and Education, 50(1), 110-124.

Körükçü, Ö., Kapıkıran, N. A. ve Aral, N. (2016). Resimli çocuk kitaplarında Schwartz’ın modeline göre değerlerin incelenmesi. Mehmet AkifErsoy Üniversitesi Eğitim Fakültesi Dergisi, 1(38), 133 151.

Kropman, M., Schoch, H.P. ve Teoh, H.Y. (2010). An experience in e-learning: using an electronic textbook. Erișiom Adresi: https://www.ascilite.org/conferences/perth04/procs/pdf/kropman.pdf.

Kul, N. (2014) Evrensel bakııs açısıyla ülkemizde 1930-2010 yullar arasında basılan resimli çocuk kitaplar (Yayımlanmamış Yüksek Lisans Tezi). Yeditepe Üniversitesi, Sosyal Bilimler Enstitüsü, İstanbul.

Lam, P., Lam, S.L., Lam, J. ve McNaught, C. (2009). Usability and usefulness of ebooks on PPCS: How students' opinions vary over time. Australasian Journal of Educational Technology, 25(1), $30-44$.

McFall, R. (2005). Electronic textbooks that transform how textbooks are used, The Electronic Library, 23 (1), 72-81.

MEB, (2013). Cocuk edebiyatina giriş: Cocuk gelişimi ve eğitimi modülü. Ankara. Erişim Adresi: http://megep.meb.gov.tr/mte_program_modul/moduller_pdf/\%C3\%87ocuk $\% 20$ Edebi yat $\%$ C4\%B1na $\% 20$ Giri $\%$ C5\%9F.pdf.

Mutlu, E., Korkut, B., ve Yılmaz, Ü. (2006). Ders kitaplarmın dağıtım amacryla internetin kullanılmasi: Açıkögretim e-kitap uygulaması örneği. Eskişehir: Açıköğretim Fakültesi Yayınları.

Naranjo-Bock, C. (2011a). Effective use of color and graphics in applications for children, part I: Toddlers and preschoolers. Erişim Adresi: www.uxmatters.com.

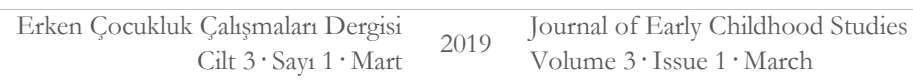


Naranjo-Bock, C. (2011b). Effective use of typography in applications for children. Erişim Adresi: https://www.uxmatters.com/mt/archives/2011/06/effective-use-of-typography-inapplications-for-children-3.php.

Onur, B. (2012). Cocuklugun ve çocuk yetiştirmenin tarihi. M. Sayıl ve B. Yağmurlu (Ed.) Ana babahk: Kuram ve araștrma, (ss. 19-59). İstanbul: Koç Üniversitesi Yayınları.

Önder, I. (2010). Elektronik kitap olgusu ve Türkiye'de durum (Yayımlanmamış Yüksek Lisans Tezi). Ankara Üniversitesi Sosyal Bilimler Enstitüsü, Ankara.

Önder, I. (2011). E-kitap ve dünyada elektronik kitap yayınc1llğı. Türk Kütüphaneciliŭi 25 (1), 97-105.

Öngöz, S. (2011, Eylül). Bir öğrenme-öğretme arac1 olarak elektronik kitap. In 5th International Computer ve Instructional Technologies Symposium, 22-24.

Pedagoji Deneği (2015). Çocuk ve ekran. Erişim Adresi: https://pedagojidernegi.com/cocuk-veekran/.

Penuel, W. R., Pasnik, S., Bates, L., Townsend, E., Gallagher, L. P., Llorente, C., ve Hupert, N. (2009). Preschool teachers can use a media-rich curriculum to prepare low-income children for school success: Results of a randomized controlled trial. New York and Menlo Park CA: Education Development Center, Inc., and SRI International.

Rukanc1, F. ve Anameriç, H. (2003). E-kitap teknolojisi ve kullanımı. Türk Kütüphaneciliği 17(2), 147166.

Sar1, N. (2006). Cocuk kitaplar illüstrasyonlan üzerine bir araşttrma ve bir örnekleme (Doktora Tezi). Dokuz Eylül Üniversitesi Eğitim Bilimleri Enstitüsü, İzmir.

Sayer, R. C. (2013). Cocuk kütü̈hanelerinde elektronik yayılarn kullanım ve yaygznlasstırlması (Yayımlanmamıs Yüksek Lisans Tezi). Ankara Üniversitesi, Sosyal Bilimler Enstitüsü, Ankara.

Schwartzman, R. ve Tuttle, H.V. (2002). What can online course components teach about instruction and learning? Journal of Instructional Psychology, 29(3) 179-188.

Sever, S. (2012). Çocuk ve edebiyat. İzmir: Tudem Yayın Grubu.

Sénéchal, M., ve LeFevre, J. (2002). Parental involvement in the development of children's reading skill: A five-year longitudinal study. Child Development, 73, 445-460.

Shamir, A., ve Korat, O. (2015). Educational electronic books for supporting emergent literacy of kindergarteners at-risk for reading difficulties-what do we know so far?. Computers in the Schools, 32(2), 105-121.

Shiratuddin, N., Landoni, M., Gibb, F. ve Hassan, S. (2003). E-book technology and its potential applications in distance education, Journal of Digital Information, 3(4), 1-10.

Somer, B. (2015) 4 - 6 Yaş resimli çocuk kitaplarnmn prososyal davranıslar açısından incelenmesi. (Yüksek Lisans Tezi). Gazi Üniversitesi Eğitim Bilimleri Enstitüsü, Ankara. 
Soydan, E. (2012) E-kitap teknolojisi ve basılı kitapların geleceği. Journal of Life Sciences, 1(1), 389399.

Şenyürek, E., Yılmaz, D. ve Köse, H. (2017). Otizmli çocukların eğitimi için mobil uygulama. Istanbul Journal of Innovation in Education, 3(1), 63-76.

Şirin, M. R. (2000). 99 Soruda çocuk edebiyatı. İstanbul: Çocuk Vakfı Yayınları.

Takacs, Z. K., Swart, E. K., ve Bus, A. G. (2015). Benefits and pitfalls of multimedia and interactive features in technology-enhanced storybooks: A meta-analysis. Review of educational research, 85(4), 698-739.

Temizyürek, F. (2014). Çocuk Edebiyatı Öğretimi Üzerine. Türk Dili Dergisi Çocuk ve İlk Gençlik Edebiyatı Özel Sayısı, 301-303.

The Guardian (2002). Ebook timeline. Erişim Adresi: https://www.theguardian.com/books/2002/jan/03/ebooks.technology.

Toran, M. ve Dilek, A. (2017). Çocuklar ve kitaplar: Piaget'nin oyun kuramına göre bir değerlendirme. Yaşadıkça Eğitim, 31 (1), 41-54.

Tuncer, N. (2018). Çocuk edebiyatının dünyadaki tarihsel gelişimi. A. Turla (Ed.) Çocuk Edebiyatı (ss.10-37). Ankara: Hedef CS Basin Yayın.

Türkiye'nin ilk elektronik kitap yarışması.(27.08.2001). Hürriyet Gą̧etesi. Erişim Adresi: http://www.hurriyet.com.tr/gundem/turkiyenin-ilk-elektronik-kitap-yarismasi-38252202.

Veziroğlu, M., ve Gönen, M. (2012). Resimli çocuk kitaplarının MEB okul öncesi eğitim programındaki kazanımlara uygunluğunun incelenmesi. Eğitim ve Bilim, 37(163), 226-238.

Walton, E. W. (2007, Mart). Faculty and student perceptions of using e-books in a small academic institution. In ACRL Thirteenth National Conference, Baltimore, MD.

Woody, W.D., Danie, D.B. ve Baker, C.A. (2010). E-books or textbooks: Students prefer textbooks, Computers ve Education, 55 (3), 945-948.

Woolley, J. D., ve Cox, V. (2007). Development of beliefs about storybook reality. Developmental Science, 10(5), 681-693.

Yalçıntaş-Sezgin, E. ve Ulus, L. (2017). The early literacy at preschool education: The book or the e-book?. Turkish Online Journal of Educational Technology-TOJET, 16(4), 77-83.

Yıldız, C., Yazıc1, D., ve Durmuşoğlu, M. (2016). 2010-2015 Yılları arasında yayımlanmış resimli çocuk kitaplarının resimleme özelliklerinin incelenmesi. Uluslararası Erken Cocukluk Eğitimi Calısmalarn Dergisi, 1(1), 43-55.

Yol, F. (2015). 4-6 yas resimli çocuk kitaplarnda çocukluk anlayısının incelenmesi(Yayımlanmamış Yüksek Lisans Tezi). Gazi Üniversitesi, Eğitim Bilimleri Enstitüsü, Ankara.

Živković, D. (2008). The electronic book: evolution or revolution?.Bilgi Dünyası,9(1), 1-20. 